\title{
Surat Kabar Kota Medan Era 4.0
}

\author{
Abdul Rasyid \\ Dosen Fakultas Ilmu Sosial UIN Sumatera Utara
}

\begin{abstract}
ABSTRAK
Penelitian ini bertujuan mengetahui kondisi surat kabar cetak di Kota Medan Era 4.0, serta faktor-faktor memengaruhi perkembangan dengan menggunakan metode analisis dokumentasi serta wawancara kalangan pers terhadap surat kabar yang selama ini diketahui memiliki minat baca tinggi. Hasil penelitian menemukakan surat kabar harian cetak di Kota Medan mencapai 30 suarat kabar berada dalam kondisi kritis bahkan diperkirakan akan kolep. Karena pemasokan iklan yang merupakan jantungnya persuratkabaran menurun derastis sampai ke tingkat paling bawah. Fakta ini ditunjukkan Harian Analisa hanya mendapatkan 3 halaman iklan yang sebelum-seblumnya mencapai 10 halaman, Waspada hanya mampu meraih 0,5 halaman iklan, Harian Tribun hanya 1,5 halaman iklan, Sumut Pos 1 halaman, Koran Mimbar Umum, Sinar Indonesia Baru, Medan Pos, dan lainnya cuma 1/4 halaman iklan, bahkan beberapa media lainnya tidak memperoleh iklan sama sekali. Penyebab rendahnya pemasukan iklan bagi surat kabar cetak, karena para pemasang iklan melarikan iklan ke media berbasis digital dengan tarif lebih murah dan gampang diakses pembaca melalui android. Sisi lain juga karena berita-berita yang disajikan media surat kabar tidak mampu menarik perhatian pembaca secara signifikan, sehingga pembaca cendrung mengabaikan berita-berita di media massa surat kabar cetak.

Apa yang dikemukakan Garnham dalam teori ekonomi politik media jelas sekali bahwa media massa termasuk media massa cetak surat kabar erat kaitannya dengan masalah ekonomi. Artinya media massa surat tidak akan hidup tanpa didukung kekuatan ekonomi. Satu-satunya yang dapat menghidupkan media massa cetak terletak pada pemasukan iklan. Teori Uses and effec juga berpandangan terhadap apa yang menjadi keinginan dan pandangan pada massa media serta akses kepada media akan membawa individu membutuhkan atau tidak membutuhkan mass media. Hal ini berkaitan dengan daya tarik berita yang disuguhkan media cetak tersebut sehingga memengaruhi sikap pembeli.
\end{abstract}

\section{Kata Kunci: Surat Kabar}

\section{PENDAHULUAN}

Istilah Industri 4.0 (Empat Titik Nol) sudah tidak asing lagi bagi kit semua orang. Pertama sekali istilah ini muncul akibat terjadinya revolusi industri di jagat bumi ini sebagai revolusi industri keempat. Hal ini terkait dengan persoalan yang memberi dampak bagi hubungan dunia dan tata cara kehidupan. Diyakini, Era Empat Titik Nol memberikan kesejahhteraan serta kualitas kehidupan umat manusia yang lebih baik.

Banyak manusia hari ini merasa terjebak masuk ke Era Empat Titik Nol yang dipandang sebagai mode otomasi dan pergantian data terkini dalam teknologi pabrik. 
Dikatakan terjebak, karena banyak manusia yang belum siap. Era tersebut juga terus menggilas kehidupan umat manusia yang tak bisa lari dari kenyataan hidupnya. Akhirnya banyak manusia yang kucar kacir dan kebingungan menyelaraskan diri, terutama bagi mereka yang berusia di atas 40 tahun.

Bagi generasi yang di era ini berusia belasan tahun memiliki keselarasan dengan perkembangan teknologi digital tersebut. Karenanya banyak mereka yang telah berusia di atas 40 tahun belajar banyak dengan generasi di bawahnya. Herman Patek menyebutkan bahwa Industri 4.0 di dalam mencakup gabungan sistem siber fisik, internet, komputasi awan (cloud computing) dan komputasi kognitif. ${ }^{1}$ Melalui komputasi awan (cloud computing), layanan internal dan lintas organisasi disediakan dan digunakan oleh bermacam pihak di dalam rantai nilai. Munculnya Era Empat Titik Nol berasal dari sebuah proyek dalam strategi teknologi canggih Negara Jerman yang mengutamakan komputerisasi pabrik. ${ }^{2}$

Sebutan Era industri 4.0 dikemukakan kembali di Hannover Fair pada sekitaran sembilan tahun silam. Kemudian bekerkan di inustri Empat Titik Nol four point zero) menyajikan rekomendasi tersebut kepada Federal Jerman setahun kemudian. Kelompok kerja four point zero merupakan tokoh pendiri dan perintis four point zero. Menurut Herman ada empat prinsip dalam era four point zero ${ }^{3}$

1. Interoperability, it is the ability of machines, devices, sensors and human to connect each other via internet to all IoT or internet for UoP. IoT will automate this process massively.

2. Information Transparency, it is the ability of information systems to create a virtual copy of physical word by enciching digital factory models by a raw sensor data to produce high value infromation.

3. Technical assistances, it is the ability to help human in colecting and visualizing an information in order to give smart decision and solve the sudden difficult problem then, the ability of physical cyber syistem to help human physically by carrying out a series of unpleasant tasks, too heavy and unsafe fo humans.

4. Independent. It is the ability of physical-cyber system to make their own decisions and do the tasks independently, if there is a cross-section interference, the task delegated to the top.

Di era four point zero inilah dunia persurat kabaran khususnya di Kota Medan nyatanya telah mengalami situasi yang sangat sulit, bahkan beberapa surat kabar sudah "meninggal dunia" karena tidak mampu lagi bernapas dengan normal. Misalnya surat kabar harian Seputar Indonesia (Sindo) Medan, Medan Bisnis, Global, Batak Pos, Bintang Sumatera, harian Sumatera. Sedangkan surat kabar yang ada seperti Waspada, Analisa, Sinar Indonesia Baru, Medan Pos, Mimbar Umum, Sumut Pos dan Tribun, Harian Orbit juga sudah mulai megap seperti kehilangan

\footnotetext{
${ }^{1}$ Herman, Patek, Otto, Design Principles for Industri 4.0 Scenarios, accessed on 9 Pebruari 2020.

${ }^{2}$ https://id.wikipedia.org/wiki/Industri_4.0. Diakses tanggal 2020-02-04.

${ }^{3}$ Herman, Mario Pantek, Design Principles for Industri 4.0 Scenarios : Aliterature Review. 2015.
} 
oksigen untuk bernapas. Faktor utama sulit dunia persurat kabaran di Kota Medan hidup di era 4.0 karena faktor munculnya media yang menggunakan sistem digital, termasuk juga kemampuan teknologi digital yang bisa dimanfaatkan untuk menyampaikan pesan-pesan iklan berbagai produk yang selama ini menjadi handalan pemasukan bagi media massa surat kabar cetak.

Surat kabar atau media cetak pada awal pertumbuhan hingga memasuki era digital cukup mengambil peran penting dalam komunikasi massa. Banyak manusia merasakan betapa pentingnya surat kabar sebagai bahan memberikan gambaran kehidupan nyata yang sedang terjadi baik menyangkut peristiwa di berbagai pelosok dunia, perkembangan pengetahuan, hiburan, ekonomi, politik, agama dan sebagainya. Karenanya posisi surat kabar menjadi bergengsi. Para pembeli surat kabar merasa bangga jika setiap harinya surat kabar bisa hadir di meja kerjanya dan tak jarang juga bagi sebagian orang merasa bangga bila membawa surat kabar pulang ke rumahnya, sehingga bisa dijadikan referensi, dan bahkan memenuhi ruang perpustakaan yang ada di rumah.

Surat kabar juga selama ini telah memenuhi pembacanya di setiap warung kopi di pinggiran jalan, di hotel, rumah makan, sehingga satu surat kabar bisa dibaca oleh banyak orang. Phillip Mayer, penulis buku The Vanishing News Paper memprediksi koran terakhir yang terbit pada April 2040. ${ }^{4}$ Hal ini akibat menurunnya pembeli surat kabar, menurun pemasang iklan, dan semakin menjamurnya berita yang disajikan melalui media baru berupa online. Akankah perkiraan Phillip Meyer juga akan memberi tanda-tanda bagi dunia persuratkabaran di Kota Medan. Kehancuran surat kabar dapat kita lihat di Amerika Serikat The Washinton Pos harus tutup karena masalah ekonomi, Tribune terpaksa fokus ke media online, The New York Time. Di Malaysia koran berusia 80 tahun bernama Utusan Malaysia juga tutup karena mengalami masalah keuangan. ${ }^{5}$ Ke jadian ini bukan karena buruknya kualitas jurnalisme, tetapi lebih karena berkurangnya pembeli surat kabar dan pemasukan iklan. Ini semua akibat berkembangnya media digital yang lebih dekat dan sangat akrab dengan para pembaca.

Nielsen Media Research released in nine cities in Indonesia (population 43.87 million with age 10 years and over), in the third quarter of 2009, newspaper consumption actually reached its lowest point in the last five years, beginning in 2005 reaching 28 percent, but continued to dive at 18 percent. Tabloids dropped from $20 \%$ to $13 \%$. This shows how difficult print newspapers are. As many as $34 \%$ of newspaper readers turn to internet users and $41 \%$ of newspaper readers also access local news from the internet. Since 2006, the percentage of young internet users has continued to increase from $12 \%$ to $20 \%$ (aged $10-14$ years) and from $24 \%$ to $33 \%$ (aged 15-19 years), whereas for ages 20-29 years has fallen from $40 \%$ to $30 \%$.

\footnotetext{
${ }^{4}$ https://tekno.kompas.com/read/2008/12/09/13223177/koran.terakhir.april.2040.

${ }^{5} \mathrm{https}: / /$ kabar24.bisnis.com/read/20190819/19/1138488/surat-kabar-tertua-di-malaysia-bakal-tutup

${ }^{6} \mathrm{http}: / /$ newspaper.pikiran-rakyat.com.
} 
Survei yang dilakukan Nielsen juga persis seperti yang ditemukan peneliti sendiri bahwa hampir seluruh mahasiswa Prodi Ilmu Komunikasi Fakultas Ilmu Sosial dan Prodi Komunikasi Penyiaran Islam Fakultas Dakwah dan Komunikasi UIN Sumut tidak lagi membaca surat kabar cetak. Para mahasiswa lebih akrab dengan media baru,atau disebut sebagai degital native yaitu generasi internet, net generation, digital generation atau para mellenials. John Palfrey dan Urs Gasser lebih jauh menjelaskan karakteristis digital native sebagai sosok yang lahir setelah tahun 1980, ketika teknologi digital usenet dan bulletin board system hadir secara online. Generasi ini mengakses teknologi jejaring digital, serta memiliki keterampilan dan pengetahun tentang komputer. ${ }^{7}$ Kemampuan lintas operasional media baru ini memberi kesempatan lebih besar untuk partisipasi aktif di media ${ }^{8}$

\section{KAJIAN TEORI}

Penelitian terhadap keberadaan media massa, termasuk media massa koran sebagai kegiatan bisnis dapat dilakukan dengan kajian berdasarkan teori ekonomi politik media. Teori dikemukakan Garnham, lembaga media massa harus dinilai sebagai bagian dari sistem ekonomi yang juga bertalian erat dengan sistem politik. Kualitas pengetahuan tentang masyarakat yang diproduksi media massa untuk masyarakat, sebagian besar dapat ditentukan dari nilai tukar berbagai ragam isi dalam kondisi yang memaksakan perluasan pesan dan juga ditentukan kepentingan ekonomi para pemilik dan penentu kebijakan. ${ }^{9}$ Perbincangan terkait sistem ekonomi selalu ada hubungannya dengan persoalan kapital atau modal dari pemilik media.

Seorang teoritikus Sosialisme, Karl Marx berpendapat, kapitalisme merupaskan sistem ekonomi yang memungkinkan beberapa orang menguasai sumber daya produksi vital yang mereka gunakan meraih keuntungan maksimal. Hubungan media massa dengan kapitalisme, menurut Stuart Hall, media massa merupakan sarana paling penting dari kapitalisme abad XX untuk memelihara hegemoni ideologi. Media massa juga menyediakan kerangka beropikir bagi berkembangnya budaya massa melalui usaha kelompok dominan yang terus menerus berusaha mempertahankan, melestarikan kepenguasaan demi menggerogoti, melemahkan dan meniadakan potensi tanding dari pihak-pihak yang dikuasai. ${ }^{10}$

Untuk bisa terus bertahan, upaya yang dapat dilakukan media massa adalah pemanfaatan teknologi informasi. Lewat penguasaan IT media massa koran misalnya dapat mealakukan efisiensi yang cukup berpengaruh terhadap daya saing media massa dalam bentuk persaingan industri media massa. Penghematan biaya dapat dilakukan terhadap produksu cetak maupun distribusi konten media massa yang dapat dilakukan dalam waktu cepat bahkan sam,pai pada struktur organisasi yang

\footnotetext{
${ }^{7}$ Isabella Astrid Sihaya, dalam buku Masa Depan Komunikasi, Masa Depan Indonesia Jurnalisme Profesional dan Literasi Media, (Jakarta Selatan : Ikatan Sarjana Komunikasi Indonesia, 2014), h. 126-127.

${ }^{8}$ Stephen W littlejohn (editor), Ensiklopedia Teori Komunikasi (Jakarta : Kencana, 2016), h.823.

${ }^{9}$ McQuail, Denis, Teori Komunikasi Massa Suatu Pengantar. (Jakarta : Erlangga, 1989), h. 98.

${ }^{10}$ Burhan Bungin, Konstruksi Sosial Media Massa, (Kencana:Jakarta, 200), h.50
} 
semakin kurus. Kemajuan Teknologi Informasi dalam industri media massa membawa pengaruh kuat bagi perubahan terhadap karakteristik media massa itu sendiri. Bahkan kemudian perbedaan karakteristik tersebut telah menjadi determinan antara media massa mainstrem dengan media baru (online) yang memiliki karakteristik berbeda akibat mengadopsi teknologi nformasi.

Uses and Effects Theory ternyata menjadi hal cukup penting dalam penelitian ini, sebab keberlangsungan media massa juga terkait dengan pengguna media itu sendiri. Uses and Effects Theory pertama kali dipikirkan oleh Sven Windahl pada tahun 1979. Adanya teori ini merupakan sentesis dari teori sebelumnya yakni Uses and Gratifications Theory dan teori tradisonal mengenai efek. Konsep use merupakan bagian sangat penting dari pemikiran ini, karena pengetahuan mengenai penggunaan media yang menyebabkan akan memberi jalan bagi pemahaman dan perkiraan tentang hasil dari suatu proses komunikasi massa. Penggunaan media massa dapat memiliki banyak makna. Ini berarti exposure yang semata-mata menunjuk pada tindakan mempersepsi. Dalam konteks lain, pengerti tersebut dapat menjadi suatu proses yang lenih kompleks, dimana isi terkait keinginan-keinginan tertentu untuk dapat dipenuhi. Fokus dari teori ini lebih kepada pengertian kedua. ${ }^{11}$ Dalam uses and gratifications, pengunaan media pada dasarnya ditentukan oleh kebutuhan dasar individu. Sementara pada uses and effect, kebutuhan hanya salah satu dari faktor yang menyebabkan terjadinya penggunaan media. Keinginan dan persepsi terhadap media, dan tingkat akses kepada media akan membawa seseorang kepada keputusan untuk menggunakan atau tidak menggunakan media massa. ${ }^{12}$

\section{METODOLOGI}

Metode yang digunakan dalam penelitian ini mencakup metode dokumentasi dengan mengumpulkan sejumlah surat kabar cetak, terutama surat kabar Waspada, Analisa, Tribun, Sumut, Sinar Indonesia Baru, Mimbar Umum yang merupakan surat kabar yang selama ini terbesat di Kota Medan yang diperoleh melalui perpustakaan yang ada Sumatera Utara. Metode dokumentasi ini menggunakan waktu cukup panjuang selama 36 bulan terakhir ini sejak 2017 hingga 2019. Kemudian penelitian ini juga melakukan observasi ke lapangan yakni di pusat-pusat penjualan koran. Ini lakukan untuk mengetahui minat baca dan daya beli masyarakat terhadap surat kanbar cetak di Kota Medan. Cartwright yang dikutip Haris Herdiansyah mendefenisikan, observasi merupakan suatu proses melihat, mengamati dan mencermati serta merekam prilaku secara sistematis untuk suatu tujuan tertentu. ${ }^{13}$

Selain itu, penelitian ini juga mengambil data melalui wawancara langsung dan mendalam dengan pihak yang berkompeten dengan dunia persuratkabaran di

\footnotetext{
${ }^{11}$ Bungin, Burhan, .Analisis Data Penelitian Kualitatif, (Jakarta : Raja Grafindo.2006 ),h. 291.

${ }^{12}$ Sendjaya, S. Djursa, Komunikasai Massa, (Jakarta : Rosdakarya, 1999), h. 291.

${ }^{13}$ Herdiansyah, Haris, Metode Penelitian Kualitatif untuk Ilmu-Ilmu Sosial, (Jakarta: Salemba, 2010), h. 131.
} 
Koa Medan, sehingga diketahui persis bagaimana kondisi dunia persuratkabaran Kota Medan hari ini. Dalam penelitian ini wawancaratermasuk hal menjadi metode pengumpulan data yang utama. Wawancara di sini adalah percakapan dua pihak yakni pewawancara (interviewer) yang mengajukan pertanyaan dan terwawancara (interviewee) yang memberikan jawaban atas pertanyaan tersebut.

\section{STUDI KASUS}

Dari puluhan surat kabar cetak yang terdapat di Kota Medan, ada dua surat kabar cetak yang perlu diamati secara serius menyangkut eksistensinya pada era industri 4.0 ini. Kedua surat kabar tersebut yakni Surat Kabar Waspada dan Analisa. Setidaknya kedua surat kabar ini menempati teras di atas 10 ribu dan memiliki cukup banyak iklan pada tiga tahun sebelumnya. Kedua surat kabar ini dapat mewakili puluhan surat kabar cetak di Kota Medan. Namun dalam tiga tahun belakangan ini kedua surat kabar ini mengalami penurunan cukup drastis baik penerimaan iklan maupun jumlah teras berita, termasuk juga puluhan surat kabar lainnya di Kota Medan.

Kajian ini lebih berorientasi pada pemuatan iklan di dua surat kabar yakni Waspada dan Analisa. Prihal ini adalah cukup signifikan bagi eksisisnya sebuah surat kabar cetak. Iklan merupakan jantungnya sebuah surat kabar. Tanpa iklan sebuah surat kabar tidak akan bisa hidup secara normal. Sebab dengan iklan media massa cetak akan mendapatkan penghasilan atau pemasukan keuangan yang utama dibanding dengan penghasilan atau keuntungan penjualan koran itu sendiri.Iklan sendiri memang membutuhkan media sebagai tempat mempromsikan berbagai jenis produk baru untuk dipasarkan. Sedangkan media massa dengan kemampuan persuasifnya dapat memarik minat pembaca terhadap produk yang diiklankan. ${ }^{14}$ Iklan yang ditampilkan media cetak surat kabar bisa disajikan dalam beberapa katagori misalnya iklan lowongan kerja, iklan otomotif, iklan property, iklan rokok, iklan elektronik, iklan jenis makanan dan minuman, iklan laporan keuangan, iklan lelang, iklan penerimaan mahasiswa baru, iklan advertorial, dan sebagainya. Semua iklan tersebut disajikan dalam bentuk berbeda.

Di harian Waspada dalam tiga tahun belakangan ini jumlah iklan produk yang terpasang hanya tinggal setengah halaman yang nilai tidak lebih dari Rp 2 juta, dengan harga iklan Rp 13.000/m/kolom Begitu juga harian Analisa yang sebelumnya mencapai 10 halaman iklan, dalam tiga tahun belakangan hanya tersisa tiga halaman iklan yang nilai sekitar Rp 30 juta, dengan harga Rp 13.000/m/kolom. Menghadapi kenyataan ini, bagaimapun sebuah surat kabar cetak tidak akan bisa hidup secara normal, karena penghasilan dari iklan tidak memberikan pemasukan untuk bisa menutupi kebutuhan sehari-hari, baik biaya produksi maupun biaya penggajian

\footnotetext{
${ }^{14}$ Morisson, Periklanan : Komunikasi Pemasaran Terpadu, (Jakarta : Kencana, 2010), h.17.
} 
pegawai dan wartawan, serta biaya lainnya yang berkaitan dengan kebutuhan perkantoran.

Faktor penyebab berkurangnya pemasang iklan di media surat kabar cetak pada era industri 4.0 karena goncangan ekonomi yang membuat peminat surat kabar berkurang juga yang tak kalah pentingnya adalah semakin berkembangnya media massa online. New media merupakan perkembangan teknologi media dan telekomunikasi yang paling mutakhir. Kunci utama yang membedakan new media dengan media tradisional adalah pada karakteristik digitisation convergence, interactivity serta networks and networking. Tidak sekedar media digital, new media dikatagorikan sebagai development of unique forms of digital media, and the remaking of more traditional media forms to adapt and adapt to the new media teknologi. ${ }^{15}$

Kurniawan dalam bukunga Transformasi Pelayanan Publik berpandangan bahwa letak perbedaan media baru dengan media tradisionil seperti surat kabar, radio dan televisi adala pada perangkat berbasis komputer yang terkoneksi kepada internet dalam hal mencari dan menerima informasi. Dengan pola tak terbatas, membuat pengguna media baru menjadi bebas dalam bermedia. ${ }^{16}$ Selain tersalur ke media online, iklan juga banyak tersalur ke media sosial, dan berbagai media lain yang berbasis digital. Akibat inilah membuat media surat kabar cetak tidak memiliki pemasukan yang memadai untuk dapat bertahan hidup. Berikut daftar di bawah beberapa surat kabar cetak yang masih bertahan hidup tetapi dalam keadaan sakit.

\section{Tabel 1}

SURAT KABAR HARIAN CETAK DI KOTA MEDAN

\begin{tabular}{|c|l|l|l|}
\hline NO & NAMA SURAT KABAR & KEBERADAAN & IKLAN/HARI \\
\hline 1 & MIMBAR UMUM & 12 HALAMAN & $1 / 4$ HALAMAN \\
\hline 2 & WASPADA & 16 HALAMAN & 0,5 HALAMAN \\
\hline 3 & MEDAN POS & 16 HALAMAN & $1 / 4$ HALAMAN \\
\hline 4 & ANALISA & 20 HALAMAN & 3 HALAMAN \\
\hline 5 & SINAR INDONESIA BARU & 16 HALAMAN & $1 / 4$ HALAMAN \\
\hline 6 & PORTIBI & 12 HALAMAN & $1 / 4$ HALAMAN \\
\hline 7 & POS METRO MEDAN & 12 HALAMAN & $1 / 4$ HALAMAN \\
\hline 8 & ANDALAS & 12 HALAMAN & $1 / 4$ HALAMAN \\
\hline 9 & SUMUT POS & 16 HALAMAN & 1 HALAMAN \\
\hline 10 & BERITA SORE & 12 HALAMAN & KOSONG \\
\hline 11 & REALITAS & 12 HALAMAN & KOSONG \\
\hline 12 & HARIAN GLOBAL & 12 HALAMAN & KOSONG \\
\hline 13 & PERJUANGAN & 12 HALAMAN & KOSONG \\
\hline 14 & PERJUANGAN BARU & 12 HALAMAN & KOSONG \\
\hline 15 & TRIBUN MEDAN & 20 HALAMAN & 1,5 HALAMAN \\
\hline 16 & HARIAN ORBIT & 12 HALAMAN & $1 / 4$ HALAMAN \\
\hline 17 & METRO 24 & 12 HALAMAN & $1 / 4$ HALAMAN \\
\hline
\end{tabular}

\footnotetext{
${ }^{15}$ Flew, Terry, New media: An Introduction (2nd edition). Oxford: Oxford University Press, 2005.

${ }^{16}$ Kurniawan, Transformasi Pelayanan Publik, (Yogyakarta : Pembaruan, 2005), h. 20
} 


\begin{tabular}{|l|l|l|l|}
\hline 18 & SUMATERA & TUTUP & \\
\hline 19 & SINDO MEDAN & TUTUP & \\
\hline 20 & BATAK POS & TUTUP & \\
\hline 21 & GAYA MEDAN & TUTUP & \\
\hline 22 & SUARA RAKYAT MEDAN & TUTUP & \\
\hline 23 & JURNAL MEDAN & TUTUP & \\
\hline 24 & BERITA MEDAN & TUTUP & \\
\hline 25 & SKALA INDONESIA & TUTUP & \\
\hline 26 & POS KOTA SUMATERA & TUTUP & \\
\hline 27 & HARIAN MANDIRI & TUTUP & \\
\hline 28 & HARIAN BERSAMA & TUTUP & \\
\hline 29 & MEDAN BISNIS & TUTUP & \\
\hline
\end{tabular}

\section{ANALISIS}

Media cetak surat kabar tidak akan bisa hidup normal tanpa mendapatkan pemasokan iklan yang memadai, sebab iklan adalah pemasukan yang cukup signifikan untuk membiaya kos sebuah perusahaan surat kabar. Surat kabar harian Waspada dan Analisa dalam tiga tahun belakangan telah mengalami penurunan pemasukan iklan. Hal ini dapat dilihat dari terbitan pada setiap harinya di setiap halaman yang tersedia. Garnham berpandangan bahwa lembaga media massa memiliki hubungan yang erat dengan masalah kepentingan ekonomi bagi pemilik media massa. Sehingga cendrung menentukan dalam membuat keputusan dan kebijakan-kebijakan politik pemiliknya. Karena itu Gernham berpandangan lembaga media massa harus dinilai sebagai bagian sistem ekonomi dan sistem politik. ${ }^{17}$

Apa yang dikemukakan Garnham jelas sekali bahwa media massa termasuk media massa cetak surat kabar erat kaitannya dengan masalah ekonomi. Artinya media massa surat tidak akan bisa hidup tanpa didukung oleh kekuatan ekonomi. Satu-satunya yang dapat menghidupkan media massa cetak terletak pada pemasukan iklannya. Jika iklan semakin banyak, maka kesejahteraan keryawan dan wartawannya akan lebih terjamin. Bila kesejahteraan tidak terjamin, maka manajemen redaksi dan perusahaan tidak dapat berjalan dengan baik, hingga sangat berpengaruh sekali dalam melahirkan jurnalisme berkualitas. Akibatnya tentu saja akan berpengaruh juga bagi daya beli pembaca terhadap media surat kabar tersebut. Jadi wajar saja kalau banyak media massa cetak tutup karena media massa tersebut tidak lagi dapat meraup iklan. Terutama dalam perkembangan teknologi digital, pemasang iklan telah beralih dari media massa cetak ke iklan digital. Akibatnya memberi dampak buruk bagi keberadaan media massa cetak seperti surat kabar.

Kota Medan memliki dua surat kabar terbesar juga telah mengalami nasib buruk yakni Harian Waspada dan Harian Analisa, karena pemasukan iklannya sudah jauh menurun, bahkan berada di level paling bawah. Ini tentu saja pada awalnya

${ }^{17}$ McQuail, Dennis, Teori Komunikasi Massa Suatu Pengantar, ( Terjemahan Agus Dharma, Jakarta : Erlangga, 1989), h.98. 
karena menurunnya minat baca masyarakat terhadap media cetak surat kabar, akibat bermunculan media massa online atau new media. Menurut Kittler, media digital telah menjadi master ontologi yang menentukan situasi. ${ }^{18}$ Di Kota Medan terdapat sedikitnya 40 media massa online yang dapat diakses setiap harinya oleh para peminat berita terkini. Di Era 4.0 inilah dunia persuratkabaran hari ini khususnya di Kota Medan nyatanya telah mengalami situasi yang sangat sulit, bahkan beberapa surat kabar sudah "meninggal dunia" karena tidak mampu lagi bernapas dengan normal. Karenanya tidak tertutup kemungkinan apa yang dikatakan Philip Mayer, seorang penulis buku berjudul The Vanishing News paper memperkirakan koran terakhir cetak pada April 2040. ${ }^{19}$

Humas Harian Waspada, Dr. H. Erwan Efendi, MA dan Pemimpin Perusahaan Mimbar Umum, Ngatirin, dan seorang wartawan Harian Analisa, Dr Ali Murtho, MA mengakui bahwa pemasukan iklan di media cetak surat kabar dalam tiga tahun belakangan mengalami penurunan cukup signifikan. Begitu juga dengan daya beli pembaca mengalami penurunan signifikan dibanding tiga tahun lalu. Mereka berdua mengakui bahwa penyebab utama menurunnya minat pemasang iklan di media cetak surat kabar tidak lain karena pengaruh teknologi digital yang dapat dimanfaatkan untuk pemasangan iklan, dan lebih cepat mengakses ke pembacanya. Karena tidak salah apa yang dikatakan bahwa dunia saat ini digoyang dengan dahsyatnya perkembangan teknologi komunikasi dan informasi. ${ }^{20}$

Ngatirin mengakui bahwa mahalnya harga kertas koran juga cukup memengaruhi akan keberadaan surat kabar. Karena dengan naiknya harga beli kertas koran, secara otomatis perusahaan surat kabar juga akan menaikkan harga jual koran ke pasaran. Ini tentu saja mempengaruhi daya beli pembaca, sementara perusahaan surat kabar juga tidak bisa hidup hanya menghandalkan pada penjualan surat kabar tanpa ada pemasukan dari iklan. Langkah yang harus dilakukan dunia persurat kabaran adalah sebagaimana dikatakan Wilson dan Ogden bahwa sebagai strategi komunikasi, pesan harus dirancangan sesuai keinginan publik sehingga memiliki kemampuan daya tarik dan mendatangkan minat atau kepentingan publik untuk mengetahui isi pesan yang disampaikan lewat media massa. Jika pesan tak sesuai dengan keinginan publik, maka pesan akan diabaikan oleh publik. ${ }^{21}$ Media massa termasuk surat kabar juga memiliki ketyergantungan kepada pihak yang memanfaatkannya atau yang mengendalikannya. ${ }^{22}$ Bagaimanapun produk utama media massa adalah berita. Berita inilah yang dikonsumsi pembaca. Menurut Dr. William C. Bayer, berita (news) merupakan suatu yang aktual dipilih jurnalis untuk

\footnotetext{
${ }^{18}$ Stephen W. Littlejohn, Karen A .Foss, Ensiklopedia Teori Komunikasi, (Jakarta : Kencana Prenadamedia Group), h. 823.

${ }^{19} \mathrm{Htt} / / /$ www.suarakarya.id/detail/104968/Optimalissasi-Inovasi-Tepis-Senjakala-Media-Cetak.

${ }^{20}$ Abdul Muis, Komunikasi Islam (Bandung : Remaja Rosdakarya, 2001), h. 329.

${ }^{21}$ Wilson, L Laurue J\& Joseph D. Ogden, Strategic Communications Planning for Effective Public Relations and Marketing Fifth Edition, (Kendall/Hunt Publishing Company, Iowa, USA, 2008), h. 41.

${ }^{22}$ Onong Uchana Effendy, Dinamika Komunikasi (Bandung : Remaja Rosdakaryam 2002), h.20.
} 
dimuat dalam surat kabar. Sebuah peristiwa layak diangkat guna diberitakan jika memiliki nilai berita. ${ }^{23}$

Menurut Eriyanto, nilai berita secara umum yang dapat menarik pembaca adalah:

a. Prominence yakni kebesaran peristiwa dan arti pentingnya

b. Humas Interest yakni mengandung yang dapat mengundang rasa sedih, senang dan ketawa para pembaca.

c. Konflik yakni suatu kejadian yang mengandung pertikaian.

d. Unisual yakni berita yang jarang terjadi seperti bencana dan fenomena alam lainnya.

e. Kedekatan peristiwa dengan khalayak media. ${ }^{24}$

Konsep yang dikemukakan Eriyanto memang harus diperhatikan para perusahaan media massa, namun demikian media massa surat kabar harus juga memperhitungan kecepatan berita sampai ke pembaca, sehingga benar-benar bisa bersaing dengan media online. Senbab media online menjadi dunia berita sebagai desa global sebagaimana dikemukakan Marshall McLuhan. ${ }^{25}$ Mengikuti teori uses and effect, media massa akan dibaca apabila mengandung unsur kebutuhan akan isi berita. Tetapi pada fakata akses pembaca kepada media cetak surat kabar semakin menurun, karena mereka merasakan tanpa modal yang mahal telah mendapatkan berita dari media-media online melalui akses android yang mereka miliki. Masalahnya saat ini kebutuhan akan media cetak surat kabar bagi kalangan pembaca sudah semakin menurun, karena mereka merasakan tanpa modal yang mahal telah mendapatkan berita dari media-media online melalui akses android yang mereka miliki.

\section{PENUTUP}

Era Industri 4.0 merupakan era yang mencelakan bagi dunia persuratkabaran dunia termasuk juga persuratkabaran di Kota Medan. Sebab Era 4.0 membuat dunia persurat kabaran kehilangan omset dari pemasukan iklan dan semakin menurunnya daya beli pembaca surat kabar, karena para pembaca telah banyak beralih kepada media massa online, media sosial, dan media digital lainnya. Tentu saja tidak ada media surat kabar di dunia ini, termasuk di Kota Medan yang bisa hidup dengan normal tanpa ada pemasukan dari iklan.

Pengaruh iklan cukup menentukan sekali bagi maju mundurnya sebuah perusahaan persuratkabaran. Persuratkabaran jika mau eksis harus mengubah pola atau gaya penyajiannya dengan berita-berita yang dapat memberi pengaruh dan daya tarik kuat bagi para pembaca, sehingga media cetak surat kabar tidak kalah bersaing

\footnotetext{
${ }^{23}$ Totok Djurito, Manajemen Penerbitan Press, (bandung : Rosdakarya, 2000), h. 47.

${ }^{24}$ Eriyanto, Analisis Naratuf, Dasar-Dasar Penerapannya dan Analisis Teks Berita (Jakarta : Pranada Media, 2007), h.106.

${ }^{25}$ Alvin Toffler, The Third Wave, (Pan Book in Assaciation With William Collins Sons\&Co.Ltd, 1980), h. 36 .
} 
dengan media massa online yang hari ini cukup ramai bermunculan dengan penyajian beritanya yang cepat.

\section{DAFTAR PUSTAKA}

Bungin, Burhan. 2000. Konstruksi Sosial Media Massa, Kencana : Jakarta.

Denis, McQuail. 1989. Komunikasi Massa Suatu Pengantar. Jakarta : Erlangga.

Djurito, Totok. Manajemen Penerbitan Press. Bandung: Rosdakarya. 2000.

Effendy, Onong Uchjana. 2002. Dinamika Komunikasi. Bandung: Remaja Rosdakarya.

Eriyanto. 2007. Analisis Naratif, Dasar-Dasar Penerapannya dan Analisis Teks Berita. Jakarta: Prenada Media.

Herdiansyah, Haris. 2002. Metode Penelitian Kualitatif Untuk Ilmu-Ilmu Sosial. Jakarta: Salemba Humanika.

Karen A. Foss, Stephen W. Littlejohn. 2006. Ensiklopedia Teori Komunikasi. Jakarta: Kencana Prenadamedia Group.

Kurniawan, Agung. 2005. Transformasi Pelayanan Publik. Yogyakarta: Pembaruan.

Littlejohn, Stephen W (editor). 2016. Ensiklopedia Teori Komunikasi. Jakarta: Kencana.

Morisson. 2010. Periklanan: Komunikasi Pemasaran Terpadu. Jakarta: Kencana.

Muis, Abdul. 2001. Komunikasi Islam. Bandung: Remaja Rosdakarya.

S. Djuarsa, Sendjaja. 1999. Komunikasi massa. Jakarta Rosdakarya.

Sihaya, Isabella Astrid. 2014. dalam buku Masa Depan Komunikasi, Masa Depan Indonesia Jurnalisme Profesional dan Literasi Media. Jakarta Selatan : Ikatan Sarjana Komunikasi Indonesia.

Terry Flew. 2005. New media: An Introduction (2nd edition). Oxford: Oxford University Press.

Toffler, Alvin. The Third Wave. 1980. Pan Book in Assiciation With William Collins Sons \& Co. Ltd.

Willson, L Laurue J \& Joseph D. Ogden. 2008. Strategic Communications Planning for Effective Public Relations and Marketing Fifth Edition. Kendal/Hunt Publishing Company, Iowa. USA.

Herman, Mario Pentek, Tobias Otto, Boris 2015 : Design Princiles for Industri 4.0 Scenarios: A Literature Review. Feb 2015.

https://id.wikipedia.org/wiki/Industri_4.0. Diakses tanggal 2020-02-04.

htt://newspaper.pikran-rakyat.com. 